\title{
PENERAPAN SISTEM MANAJEMEN KEBAKARAN DI PT. ADILUHUNG SARANASEGARA INDONESIA, BANGKALAN
}

\author{
APPLICATION OF FIRE MANAGEMENT SYSTEM IN PT. ADILUHUNG \\ SARANASEGARA INDONESIA, BANGKALAN
}

\author{
Ranggi Nugraha \\ CV. Bumi Lestari, Surabaya \\ E-mail: rangginugraha1@gmail.com
}

\begin{abstract}
PT. Adiluhung Saranasegara Indonesia, Bangkalan are ship building and ship repair industry. This company has high risk of fire. This company used LPG for cutting the iron plate process and making new vessels. Based on the the fire triangle theory, a fire could occur if there is an element of fuel, oxygen and heat. An element of fuel which can cause a fire include solids, liquids and gases. This research aims were to identify the management systems of fire in PT. Adiluhung Saranasegara Indonesia, Bangkalan which includes pre-fire program and currently fire. This study applied descriptive study using cross-sectional approach. There were fifteen informants took part in this study that consisted of head officer, safety officer, health safety and environment (HSE) staff, firemans and securities. Data were collected by conducting interviews, observations, and document reviews. Content and data analysis were used and presented in the form of narration. The results showed that all the pre-fire program (policies in management, organization, and procedures; the identification of the risks of fire, development and training, active and passive protections towards the incidence of fire, fire inspection, the prevention of damages) has been carried out. On-fire program also have emergency respons team.
\end{abstract}

Keywords: during a fire, pre fire, shipping industry

\begin{abstract}
ABSTRAK
PT. Adiluhung Saranasegara Indonesia, Bangkalan merupakan salah satu perusahaan yang bergerak di bidang industri perkapalan yaitu tempat pembuatan dan reparasi kapal. Perusahaan ini memiliki potensi risiko bahaya kebakaran yang cukup besar. Perusahaan ini menggunakan gas elpiji sebagai salah satu alat bantu utama dalam proses pemotongan plat besi sebagai bahan dasar utama dalam memperbaiki dan membuat kapal baru. Berdasarkan teori segitiga api, kebakaran dapat terjadi jika ada unsur bahan bakar, oksigen dan panas. Unsur bahan bakar yang dapat menimbulkan api meliputi bahan padat, cair dan gas. Penelitian ini bertujuan untuk mengidentifikasi sistem manajemen kebakaran di PT. Adiluhung Saranasegara Indonesia, Bangkalan yang meliputi program pra kebakaran dan saat kebakaran. Desain penelitian menggunakan pendekatan cross sectional dan dianalisa secara deskriptif. Sampel dari penelitian ini adalah kepala biro, petugas keselamatan, staf K3LH, petugas pemadam dan orang sekuriti yang berjumlah 15 orang. Metode pengumpulan data melalui wawancara, observasi dan telaah dokumen. Analisa yang digunakan adalah analisa isi dan data disajikan dalam bentuk narasi. Hasil penelitian didapatkan, semua program pra kebakaran (kebijakan manajemen, organisasi dan prosedur, identifikasi bahaya kebakaran, pembinaan dan pelatihan, sarana proteksi kebakaran aktif dan pasif, inspeksi kebakaran, pengendalian bahaya/ pencegahan) telah dilakukan. Program saat kebakaran telah memiliki tim tanggap darurat.
\end{abstract}

Kata kunci: industri perkapalan, pra kebakaran, saat kebakaran

\section{PENDAHULUAN}

Sistem manajemen kebakaran adalah sebuah upaya dalam pengelolaan risiko kebakaran meliputi perencanaan, pelaksanaan, pemantauan, dan tindak lanjut (Ramli, 2010). Sistem manajemen kebakaran yang baik dan optimal sangat diperlukan dalam setiap unit tempat kerja di Indonesia mengingat Indonesia merupakan salah satu negara yang cukup sering terjadi bencana kebakaran. Sistem manajemen ini juga telah diatur dalam Keputusan Menteri Tenaga Kerja Republik Indonesia Nomor 186 tahun 1999 tentang unit Penanggulangan Kebakaran di Tempat Kerja, Peraturan Menteri Transmigrasi Nomor 4 Tahun 1980 tentang Syarat-Syarat Pemasangan dan Pemeliharaan APAR, dan Peraturan 
Menteri Tenaga Kerja Nomor 2 Tahun 1983 tentang instalasi Alarm Kebakaran Automatik.

Data kebakaran provinsi DKI Jakarta, diketahui bahwa sebanyak 742, 902, 855, dan 98 kali kebakaran terjadi pada tahun 2005, 2006, 2007, dan 2008 secara berturut-turut (Dinas Pemadam DKI, 2009). Data ini belum dapat mewakili daerah-daerah lain di Indonesia dengan kesadaran sistem manajemen kebakaran yang masih rendah. Hal ini membuktikan bahwa kebakaran adalah masalah serius dan harus ditanggulangi dengan baik guna menjaga keamanan dan keselamatan tenaga kerja seperti yang telah diatur dalam Undang-undang Nomor 1 Tahun 1970 tentang Keselamatan Kerja.

Berdasarkan masalah di atas, dilakukan penelitian untuk meninjau sistem kebakaran yang ada di tempat kerja dan berfokus pada PT. Adiluhung Saranasegara Indonesia yang bertempat di Bangkalan. PT. Adiluhung Saranasegara Indonesia, Bangkalan adalah perusahaan yang bergerak di bidang industri perkapalan; tempat pembuatan dan reparasi kapal. Perusahaan tersebut dipilih karena telah memenuhi syarat teori segitiga api yang menjelaskan bahwa timbulnya kebakaran dipengaruhi oleh tiga hal, yakni bahan bakar, sumber panas, dan oksigen. Bahan bakar yang terdapat dalam PT. Adiluhung Saranasegara Indonesia, Bangkalan adalah gas LPG, plastik dan kayu. Gas LPG sebagai bahan baku utama memperbaiki dan membuat kapal baru, sedangkan plastik dan kayu adalah bahan interior kapal yang mudah terbakar. Sumber panas diperoleh melalui metode las yang digunakan perusahaan untuk menyambungkan plat dan api yang keluar dari brender, keduanya berpotensi menimbulkan kebakaran. Sementara oksigen dapat diperoleh dengan mudah karena area galangan berada di udara terbuka.

Tujuan dalam penelitian ini adalah untuk mengidentifikasi program pra kebakaran dalam sistem manajemen kebakaran dan mengidentifikasi program saat kebakaran PT. Adiluhung Saranasegara Indonesia, Bangkalan. Terkait tujuan pertama akan difokuskan pada kebijakan manajemen, organisasi, dan prosedur, identifikasi bahaya kebakaran, pembinaan dan pelatihan, sistem proteksi kebakaran, inspeksi kebakaran, dan pengendalian bahaya dan pencegahan di PT. Adiluhung Saranasegara Indonesia, Bangkalan.

\section{METODE}

Penelitian ini merupakan jenis penelitian observational yang dianalisis secara deskriptif, yaitu memberikan gambaran tentang Pengaruh Penerapan Sistem Manajemen Kebakaran terhadap Insiden Kebakaran yang terdapat di PT. Adiluhung Saranasegara Indonesia, Bangkalan. Ditinjau berdasarkan segi waktu penelitian maka penelitian ini merupakan penelitian cross sectional karena dilakukan satu kali dan dalam jangka waktu tertentu.

Sasaran penelitian ini adalah pihak-pihak yang berwenang dalam pelaksanaan Sistem Manajemen Kebakaran di PT. Adiluhung Saranasegara Indonesia, Bangkalan, yaitu Kepala Biro QHSE, Staf K3, Safety Officer, 7 Pemadam dan 5 Sekuriti.

Lokasi penelitian dilakukan di PT. Adiluhung Saranasegara Indonesia, Bangkalan, di Desa Ujung Piring, Kabupaten Bangkalan, Madura. Penelitian ini berlangsung selama 1 minggu yaitu pada minggu keempat November 2016 hingga minggu pertama Desember 2016.

Penelitian ini lebih terfokus maka dibagi dalam dua program yaitu program Pra Kebakaran dan program Saat Kebakaran. Yang pertama adalah program Pra kebakaran terdiri dari kebijakan manajemen, organisasi dan prosedur, identifikasi bahaya kebakaran, pembinaan dan pelatihan, sistem proteksi kebakaran aktif maupun pasif, inspeksi kebakaran dan pengendalian bahaya atau pencegahan. Pertama adalah kebijakan manajemen, kebijakan manajemen merupakan program pengendalian dan penanggulangan kebakaran dalam perusahaan yang tertulis dan ditandatangani oleh pengurus. Kedua adalah organisasi dan prosedur merupakan suatu organisasi prosedur yang dibentuk dan bertugas untuk mencegah dan menanggulangi kebakaran. Ketiga identifikasi bahaya kebakaran adalah suatu kegiatan mengidentifikasi segala aspek yang dapat menyebabkan kebakaran. Keempat adalah pembinaan dan pelatihan merupakan suatu program kegiatan yang terjadwal mengenai pembinaan dan pelatihan teknik penanggulangan kebakaran, teknik penyelamatan (rescue), cara pertolongan pertama (P3K), dan penggunaan peralatan kebakaran. Kelima adalah sistem proteksi kebakaran (aktif dan pasif), untuk sistem proteksi kebakaran aktif merupakan suatu sarana proteksi kebakaran yang harus 
digerakkan agar dapat memadamkan kebakaran meliputi; alarm kebakaran, APAR, dan Hydrant. Sistem proteksi kebakaran pasif meliputi; tangga darurat, pintu darurat, dan mustar station. Keenam adalah inspeksi kebakaran merupakan suatu kegiatan inspeksi peralatan pemadam kebakaran agar alat yang tersedia selalu siap digunakan saat keadaan darurat. Terakhir dalam program Pra Kebakaran adalah pengendalian bahaya atau pencegahan yaitu upaya mencegah atau menghindari terjadinya kebakaran dengan melakukan langkah-langkah preventif.

Program saat kebakaran di PT. Adiluhung Saranasegara Indonesia, Bangkalan, yaitu Tim Tanggap Darurat. Tim Tanggap Darurat merupakan suatu pernyataan tertulis yang memuat adanya organisasi berupa tim atau unit kerja khusus yang dibentuk dan ditugasi untuk mengatasi masalah kebakaran.

Penelitian ini menggunakan teknik pengumpulan data primer dan sekunder, pada data primer berasal dari hasil wawancara dan observasi, sedangkan pada data sekunder diperoleh dari kepala biro QHSE. Keseluruhan variabel dalam penelitian ini telah dilakukan proses wawancara dan observasi, hanya pada variabel organisasi dan prosedur data ditambahkan dengan melihat data sekunder.

Instrumen pengumpulan data penelitian ini dibagi menjadi dua, yaitu wawancara dan observasi. Wawancara dilakukan dengan Staf K3, koordinator latihan dan pencegahan kebakaran serta wawancara kepada pekerja. Observasi dilakukan pengamatan lapangan mengenai penerapan sistem manajemen kebakaran di PT. Adiluhung Saranasegara Indonesia, Bangkalan.

Teknik analisis data dalam penelitian ini menggunakan teknik analisis deskriptif dengan metode kasus, yaitu mengungkapkan suatu masalah dan keadaan sesuai adanya dalam bentuk narasi untuk mempermudah pembacaan hasil penelitian, hanya merupakan penyingkapan fakta, dan dibandingkan dengan teori untuk menarik suatu kesimpulan sebagai akhir penelitian.

\section{HASIL}

Berdasarkan hasil wawancara yang telah dilakukan di PT. Adiluhung Saranasegara Indonesia, Bangkalan terdapat beberapa kebijakan manajemen tentang pencegahan dan penanggulangan kebakaran, yang pertama kebijakan sistem manajemen terpadu
(SMT) yaitu memastikan setiap pekerjaan panas khususnya perbaikan kapal, wajib disediakan seorang pemadam kebakaran atau lebih, hal tersebut disesuaikan dengan kondisi yang ada di kapal seberapa besar risiko terjadinya kebakaran dan seberapa banyak titik pekerjaan panas yang dilakukan oleh tim repair. Selain itu dibuatkan Working Instruction (WI) di setiap pekerjaan panas untuk meminimalisir terjadinya insiden atau kebakaran, dan yang terakhir terdapat pula Contingency Procedure Manual (CPM) penanggulangan kebakaran sebagai prosedur apabila terjadi kebakaran.

PT. Adiluhung Saranasegara Indonesia, Bangkalan berkomitmen untuk mencapai tujuan di atas dengan mengambil langkah yaitu pertama adalah memenuhi beberapa persyaratan yang tertera pada ISO 9001:2008 tentang Sistem Manajemen Mutu, ISO 14001:2004 tentang Sistem Manajemen Lingkungan, OHSAS 18001:2007 tentang Sistem Manajemen Keselamatan dan Kesehatan Kerja, dan menyesuaikan dengan petunjuk dan standar yang ada pada klasifikasi dan kualifikasi organisasi NonPemerintah yang relevan. Setelah langkah pertama terpenuhi selanjutnya adalah mengembangkan manual sistem manajemen terpadu yang meliputi sistem manajemen mutu, sistem manajemen lingkungan, serta sistem manajemen keselamatan dan kesehatan kerja dengan tujuan melibatkan seluruh karyawan yang akan digunakan sebagai panduan yang harus dipatuhi oleh seluruh karyawan. Setelah kedua langkah tersebut terpenuhi, selanjutnya adalah peningkatan pemahaman dan keterampilan serta kemampuan karyawan secara berkala dengan cara memberikan pelatihan terhadap karyawan agar karyawan tersebut berkompeten di dalam bidangnya. Setelah dilakukan pelatihan terhadap karyawan, perusahaan juga menjamin cara kerja yang aman, ramah lingkungan, serta produktif demi tercapainya kualitas produk yang sesuai. Terakhir adalah melaksanakan training atau pelatihan yang dibutuhkan oleh para karyawan di setiap bagian.

Selain kebijakan sistem manajemen terpadu, Organisasi kebakaran merupakan hal yang sangat penting demi tercapainya kualitas produk yang aman. PT. Adiluhung Saranasegara Indonesia, Bangkalan telah memiliki organisasi kebakaran atau yang biasa disebut tim tanggap darurat (Emergency Response Team) sejak 8 Oktober 2013, tim ini terbentuk sesuai dengan tugas dan tanggung jawab dari masing-masing bagian. Uraian tugas dan 
tanggung jawab anggota Tim Tanggap darurat di PT. Adiluhung Saranasegara Indonesia, Bangkalan terdapat pada Tabel 1.

Posedur keadaan darurat (kebakaran), PT. Adiluhung Seranasegara Indonesia, Bangkalan telah memiliki prosedur keadaan darurat (kebakaran) yang tertulis dalam Contingency Procedure Manual (CPM) dan prosedur ini wajib ditaati oleh seluruh karyawan PT. Adiluhung Saranasegara Indonesia, Bangkalan.

Identifikasi bahaya kebakaran, identifikasi kebakaran di PT. Adiluhung Saranasegara Indonesia, Bangkalan berupa Hazzard Identification Risk AssesSment Determining Control (HIRADC). Identifikasi tersebut telah dilakukan oleh biro QHSE sejak tahun 2011 dan memaparkan dua produk, yakni proses pembuatan kapal baru dan pelayanan jasa repair, hal tersebut merupakan aktivitas yang sangat rentan terhadap kebakaran karena proses pekerjaan dalam pembuatan kapal baru dan repair kapal didominasi oleh pekerjaan panas yang berupa pekerjaan pemotongan plat atau pekerjaan pengelasan yang bisa menghasilkan pijar atau bunga api, terlebih pada kapal repair dengan risiko tertinggi karena terdapat barang-barang yang mudah terbakar di dalamnya yang berupa bahan bakar minyak serta barang interior dari dalam kapal itu sendiri.

Pembinaan dan pelatihan, program ini telah terlaksana dan terjadwal dengan baik. Program ini dilakukan setiap 2 bulan sekali untuk melatih karyawan internal dan sub-kontraktor mengenai cara penggunaan APAR dan hydrant agar pada saat keadaan darurat terjadi seluruh personil yang berada di area galangan PT. Adiluhung Saranasegara Indonesia, Bangkalan mengetahui dan dapat menanggulangi kebakaran dengan cepat. Pembinaan dan pelatihan ini juga tidak hanya terfokus dalam penanggulangan kebakaran melainkan cara pencegahan kebakaran, jadi setiap karyawan dan subkontraktor dilatih untuk menganalisa bahaya yang ada di sekitar sehingga dapat mencegah terjadinya kebakaran. Program ini juga dilengkapi dengan pelatihan P3K yang bertujuan apabila terjadi insiden agar seluruh personil dapat memberikan tindakan penyelamatan yang baik dan benar tanpa harus menunggu tim medis. Selain program pelatihan dan pembinaan dasar, dilakukan pula program Emergency Drill setahun sekali bagi karyawan berwenang sebagai sarana pelatihan tanggap darurat. Tujuan diberlakukannya hal tersebut adalah untuk mengetahui respons dari seluruh personil yang ada di PT. Adiluhung Saranasegara Indonesia, Bangkalan jika terjadi keadaan darurat berupa kebakaran.

Proteksi kebakaran, PT. Adiluhung Serana segara Indonesia, Bangkalan memiliki 2 sistem proteksi kebakaran, yakni aktif dan pasif. Sistem proteksi aktif adalah sarana proteksi kebakaran yang harus digerakkan dengan sesuatu untuk berfungsi memadamkan kebakaran sedangkan sistem proteksi pasif adalah sistem proteksi kebakaran yang menjadi kesatuan atau bagian dari suatu rancangan atau benda. Sistem proteksi kebakaran aktif di PT. Adiluhung Saranasegara Indonesia, Bangkalan meliputi: 1) Alarm kebakaran (bell), 2) Alat pemadam api ringan (APAR), terdiri dari 43 unit APAR meliputi: Dry Chemical Powder 33 unit dan Foam 10 unit yang selalu dilakukan pemeriksaan setiap sebulan sekali dengan memperhatikan kondisi tabung APAR, tekanan serta kedaluwarsa dari tabung APAR tersebut, dan 3) Hydrant sebanyak 2 unit, area Slip Way memiliki 4 pilar hydrant dengan 1 motor hydrant, sedangkan area Floating Dock memiliki 2 pilar hydrant dengan 1 motor hydrant dan dilakukan pemeriksaan setiap sebulan sekali dan juga apabila terdapat kapal repair yang sedang docking. Sistem kebakaran pasif di PT. Adiluhung Saranasegara Indonesia, Bangkalan meliputi: 1) Jalur evakuasi, sistem ini menunjuk seorang swiper yang bertugas untuk memastikan tidak ada korban yang tertinggal, mengarahkan korban mengikuti sign ke arah mustar station dan 2) Mustar station, tempat titik kumpul evakuasi yang terletak di depan kantor utama dan seorang safety master yang akan memberikan arahan untuk tidak panik.

Inspeksi kebakaran, inspeksi kebakaran dilakukan oleh beberapa tim, yakni tim Petugas Keamanan dan Disiplin (PKD) dilakukan pemeriksaan sehari dua kali untuk melakukan pengecekan pada alat travo las dan kelistrikan di seluruh area galangan serta memastikan gas LPG tidak ada yang bocor agar terhindar dari terjadinya insiden kebakaran, tim pemadam mengecek keberfungsian motor hydrant yang dilakukan setiap satu bulan sekali, dan biro QHSE melakukan inspeksi pada APAR yang dilakukan setiap satu bulan sekali dan dilakukan pelaporan sesuai dengan permenakertrans setiap enam bulan sekali dan inspeksi hydrant yang dilakukan setiap bulan dan apabila terdapat kapal sedang docking untuk memastikan bahwa APAR dan hydrant siap 
untuk digunakan dan tidak terdapat kendala apabila terjadi insiden kebakaran. Inspeksi dilakukan dengan memberikan checklist pada lembar observasi kelengkapan dan fungsi APAR dan hydrant, misalnya
APAR masih memiliki tekanan yang cukup, pin APAR tidak terbuka dan masih terpasang, dan motor hydrant berfungsi dengan baik.

Tabel 1. Tugas dan Tanggung Jawab Tim Tanggap Darurat PT. Adiluhung Saranasegara Indonesia, Bangkalan 2016

\section{Wewenang dan Tanggung Jawab Tim Tanggap Darurat}

\section{Ketua Tanggap Darurat}

1. Menentukan dan memutuskan Kebijakan Tanggap Darurat di PT. Adiluhung Saranasegara Indonesia, Bangkalan

2. Mengajukan anggaran dana yang berkaitan dengan sarana dan prasarana tanggap darurat Perusahaan.

3. Mengundang partisipasi seluruh karyawan untuk melangsungkan latihan tanggap darurat di lingkungan Perusahaan.

4. Menjadwalkan pertemuan rutin maupun non rutin Unit Tanggap Darurat.

5. Menyusun rencana pemulihan keadaan darurat Perusahaan.

\section{Sekretaris Tanggap Darurat}

1. Membuat laporan kinerja Unit Tanggap Darurat.

2. Melakukan pemantauan kebutuhan dan perawatan sarana dan prasarana tanggap darurat Perusahaan.

3. Melaksanakan kerjasama dengan pihak terkait yang berkaitan dengan tanggap darurat Perusahaan.

\section{Koordinator Tanggap Darurat}

1. Mengkoordinasi kinerja semua regu Unit Tanggap Darurat.

\section{Regu Pemadam Kebakaran}

1. Melangsungkan pemadaman kebakaran menggunakan semua sarana pemadam api di lingkungan Perusahaan secara aman, selamat dan efektif.

2. Melaporkan segala kekurangan atau kerusakan sarana dan prasarana pemadam api di lingkungan Perusahaan kepada Koordinator, Sekretaris maupun Ketua Unit Tanggap Darurat.

\section{Regu Evakuasi dan P3K}

1. Memimpin prosedur evakuasi secara aman, selamat dan cepat.

2. Melaporkan segala kekurangan/kerusakan sarana dan prasarana evakuasi di lingkungan Perusahaan kepada Koordinator, Sekretaris maupun Ketua Unit Tanggap Darurat.

3. Melaporkan adanya korban tertinggal, terjebak ataupun teruka kepada Regu P3K, Koordinator maupun Sekretaris Unit Tanggap Darurat.

4. Melaksanakan tindakan P3K.

5. Melaporkan segala kekurangan/kerusakansarana dan prasarana P3K di lingkungan Perusahaan kepada Koordinator, Sekretaris maupun Ketua Unit Tanggap Darurat.

6. Melaporkan kepada Koordinator ataupun Sekretaris Unit Tanggap Darurat jika terdapat korban yang memerlukan tindakan medis lanjut pihak ketiga di luar Perusahaan.

\section{Regu Humas dan Akomodasi}

1. Memantau perkembangan penanganan kondisi darurat dan menjembatani komunikasi antar regu Unit Tanggap Darurat.

2. Memastikan alur komunikasi antar regu Unit Tanggap Darurat dapat dilangsungkan secara baik dan lancar.

3. Memantau seluruh informasi internal dan mengakomodasi informasi/pemberitaan untuk pihak luar (press conference).

4. Menghubungi pihak eksternal terkait untuk kepentingan tanggap darurat (Kepolisian/Warga).

5. Mengakomodasi sarana transportasi darurat dari dalam/luar lingkungan Perusahaan.

6. Mengakomodasi kebutuhan umum tanggap darurat.

\section{Regu Peralatan}

1. Mengakomodasi fasilitas dan peralatan yang dibutuhkan tanggap darurat

\section{Regu Keamanan}

1. Melaksanakan tindakan keamanan internal maupun eksternal selama berlangsungnya tanggap darurat Perusahaan. 
Pengendalian bahaya atau pencegahan, PT. Adiluhung Saranasegara Indonesia, Bangkalan telah memiliki fireman atau petugas pemadam yang bertugas memastikan kondisi pada setiap area yang berisiko terjadinya kebakaran. Apabila kebakaran terjadi, fireman atau petugas pemadam mampu memadamkan api sejak munculnya kebakaran kecil. Seorang fireman atau petugas pemadam di bekali APAR karena cukup sulit untuk mobilisasi jika penggunaan hydrant ketika menjaga kapal repair.

Sebuah upaya dalam bentuk peraturan juga telah dilakukan oleh PT. Adiluhung Saranasegara Indonesia, contohnya dengan melarang karyawan merokok di area produksi dan telah menyediakan smoking area. Selain hal tersebut, PT. Adiluhung Saranasegara Indonesia, Bangkalan juga menyediakan rambu-rambu keselamatan di setiap area yang berisiko.

PT. Adiluhung Saranasegara Indonesia, Bangkalan memiliki tim tanggap darurat yang telah bekerja sesuai dengan tugas dan tanggung jawab masing-masing. Tim ini memiliki 44 orang anggota, diketuai oleh direktur SDM, dan dilengkapi dengan koordinator, serta sekretaris. Tim ini dibagi dalam 8 divisi, yakni divisi evakuasi, pemadam kebakaran, P3K, logistik, transportasi, keamanan, komunikasi internal dan komunikasi eksternal. Tim ini mendapatkan pelatihan emergency drill 1 kali dalam setahun yang difasilitasi oleh biro QHSE. Kelemahan dari tim ini adalah tidak dapat beroperasi 24 jam dan hanya beroperasi saat jam kerja, sedangkan tanggung jawab di luar jam kerja diambil alih sementara oleh tim sekuriti.

\section{PEMBAHASAN}

Hasil observasi dan wawancara yang telah dilakukan bahwa di PT. Adiluhung Saranasegara Indonesia, Bangkalan pernah terjadi kebakaran sehingga perlu adanya suatu kebijakan dari manajemen untuk menurunkan angka kebakaran yang ada sehingga menjadi zero kebakaran. Perusahaan ini juga memiliki sistem manajemen terpadu yang merupakan perpaduan dari tiga sistem manajemen yaitu: ISO 9001:2008 tentang sistem manajemen mutu, ISO14001:2004 tentang sistem manajemen lingkungan dan OHSAS 18001:2007 tentang sistem manajemen keselamatan dan kesehatan kerja. OHSAS sendiri merupakan sistem manajemen $\mathrm{K} 3$ yang di dalamnya terdapat klausul-klausul yang mengatur manajemen K3 . Hal ini sudah sesuai dengan Peraturan Pemerintah nomor: 50 tahun 2012 tentang Penerapan Sistem Manajemen Keselamatan Kesehatan Kerja yang menyatakan bahwa perusahaan wajib menetapkan kebijakan, keselamatan, kesehatan kerja, dan menjamin komitmen terhadap penerapan SMK3.

Upaya pencegahan kebakaran diperlukan pengorganisasian yang baik, misalnya dengan pembentukan organisasi yang sesuai seperti organisasi kebakaran, baik yang berupa struktural maupun yang bersifat non struktural. Di PT. Adiluhung Saranasegara Indonesia, Bangkalan telah terdapat organisasi khusus untuk pencegahan dan penanggulangan kebakaran. Pada perusahaan sudah membentuk tim tanggap darurat kebakaran yang terdiri dari: ketua tim tanggap darurat, sekretaris tim tanggap darurat, koordinator tim tanggap darurat, regu pemadam kebakaran, regu evakuasi dan P3K, regu humas dan akomodasi, regu peralatan dan regu keamanan. Hal ini sudah sesuai dengan teori dari Ramli, 2010 dalam buku Petunjuk Praktis Manajemen Kebakaran yaitu untuk mengelola upaya pencegahan kebakaran diperlukan pengorganisasian yang baik, misalnya dengan membentuk organisasi kebakaran, baik yang bersifat struktural maupun yang bersifat non-struktural.

Hasil penelitian yang dilakukan di PT. Adiluhung Saranasegara Indonesia, Bangkalan menunjukkan bahwa sudah terdapat prosedur tertulis mengenai pencegahan dan penanggulangan apabila terjadi insiden kebakaran yang telah memuat peran dan tugas dari masing-masing karyawan dan tim atau regu dari tim tanggap darurat. Perusahaan memiliki prosedur keadaan darurat yang tertulis dalam Kontingensi Prosedur Manual. Didalam Kontingensi Prosedur Manual, terdapat alur komunikasi penanggulangan kebakaran apabila terjadi kebakaran. Hal ini telah sesuai dengan Keputusan Menteri Tenaga Kerja R.I No. :Kep186/MEN/1999 tentang Unit Penanggulangan Kebakaran di Tempat Kerja yang menyatakan bahwa untuk menanggulangi kebakaran di tempat kerja, diperlukan adanya peralatan proteksi kebakaran yang memadai, petugas penanggulangan insiden kebakaran yang di tunjuk khusus oleh perusahaan, serta dilaksanakannya prosedur penanggulangan keadaan darurat dan sesuai dengan Keputusan Menteri Tenaga Kerja R.I No : KEP-186/MEN/1999 tentang Unit Penanggulangan Kebakaran di Tempat Kerja Bab 1 Pasal 2 ayat 4d yang menyatakan bahwa rencana penanggulangan keadaan darurat kebakaran harus terdapat prosedur dalam menghadapi keadaan darurat bahaya kebakaran. 
Langkah awal untuk mengembangkan sistem manajemen kebakaran adalah dengan melakukan identifikasi dan penilaian untuk mengetahui risiko-risiko kebakaran yang ada di PT. Adiluhung Saranasegara Indonesia, Bangkalan. Risiko kebakaran yang terdapat di pekerjaan perbaikan kapal merupakan risiko kebakaran terbesar yang ada pada PT. Adiluhung Saranasegara Indonesia, Bangkalan karena setiap kapal-kapal yang mengalami perbaikan apabila ada pekerjaan panas penggantian plat yang plat tersebut berisi minyak bahan bakar dari kapal yang merupakan bahan yang sangat mudah terbakar yang akan memicu terjadinya kebakaran apabila terkena panas atau percikan api dari pekerjaan panas tersebut. Pekerjaan yang berisiko juga apabila terdapat pekerjaan panas di dalam kapal yang sedang diperbaiki yang di dalamnya telah terpasang banyak interior yang sangat mudah terbakar seperti kursi, pintu dan lain-lain yang terbuat dari bahan plastik atau kayu yang mudah terbakar apabila terkena percikan api hasil pekerjaan panas tersebut. Mengingat risiko terjadinya kebakaran tinggi, maka identifikasi dan penilaian risiko dilakukan secara rinci tentang penyebab kebakaran serta pengendalian yang dibutuhkan apabila terjadi kebakaran. Hal tersebut telah dibuat oleh perusahaan dalam Form HIRADC yang selalu dilakukan pembaharuan setiap tahunnya. Tanpa mengetahui apa masalah atau lawan yang akan dihadapi maka program pengendalian dan penanggulangan kebakaran tidak akan berjalan dengan baik.

Pembinaan dan pelatihan merupakan faktor penting dalam pencegahan dan penanggulangan kebakaran. Hal ini disebabkan karena adanya faktor manusia sebagai penyebab utama terjadinya kebakaran, namun selain sebagai penyebab utama manusia juga berperan penting dalam pencegahan dan penanggulangan kebakaran. PT. Adiluhung Saranasegara Indonesia, Bangkalan juga telah memberikan pelatihan internal dari Biro QHSE untuk seluruh karyawan dan sub kontraktor berupa pelatihan penggunaan APAR dan hydrant yang dilakukan setiap dua bulan sekali dengan tujuan agar seluruh personil yang berada di area galangan PT. Adiluhung Saranasegara Indonesia, Bangkalan mengetahui dan dapat mengoperasikan APAR dan hydrant dengan baik dan benar agar apabila terjadi kebakaran bisa langsung dilakukan penanggulangan oleh pekerja yang berada di lokasi kejadian sebelum petugas pemadam tiba di lokasi. namun yang lebih penting adalah pekerja dapat menganalisa dan dapat melakukan pencegahan kebakaran sebelum kebakaran itu terjadi. Selain pelatihan tersebut, PT. Adiluhung Saranasegara Indonesia, Bangkalan juga melakukan Emergency Drill yang dilakukan setiap setahun sekali. Hal ini telah sesuai dengan UU No. 1 Tahun 1970 yang menyatakan bahwa pengurus diwajibkan menyelenggarakan pembinaan bagi seluruh pekerja. Saat dibutuhkan untuk memberikan pertolongan pertama pada korban apabila terjadi keadaan darurat, karyawan juga dibekali dengan pelatihan pertolongan pertama pada kecelakaan (P3K).

Sistem proteksi kebakaran aktif di PT. Adiluhung Saranasegara Indonesia, Bangkalan diantaranya adalah Alarm Kebakaran, Alat Pemadam Api Ringan (APAR), dan Hydrant. Sedangkan untuk sarana proteksi kebakaran pasif berupa Jalur Evakuasi dan Mustar Station. Proteksi kebakaran aktif yang terdapat di PT. Adiluhung Saranasegara Indonesia, Bangkalan meliputi yang pertama adalah Alarm Kebakaran, PT. Adiluhung Saranasegara Indonesia telah memasang alarm di setiap area yang merupakan area produksi termasuk dermaga dan fabrikasi. Pemeliharaan dan pengujiannya dilakukan berbarengan dengan Emergency Drill. Namun pemeliharaan dan pengujian alarm saat Drill dilakukan, sebelumnya dilakukan pengujian oleh sub Divisi Listrik menguji Alarm masih berfungsi dengan baik atau tidak, hal ini belum sesuai dengan Permenaker No. Per.02/Men/1983 tentang Instalasi Alarm Kebakaran Automatik karena yang dipasang hanya pada kapal saja dan tidak dipasang pada bangunan yang berupa gedung. Alat proteksi aktif yang selanjutnya adalah Alat Pemadam Api Ringan (APAR), APAR diletakkan pada posisi yang mudah dilihat dan mudah dijangkau, setiap APAR juga terpasang di dinding dengan penguat sekang atau ditempatkan dalam lemari (Box) yang dikunci dan diberi kaca pengaman. Seluruh tabung APAR berwarna merah dan terdapat petunjuk lokasi APAR, jarak antara APAR satu dengan APAR kedua tidak melebihi 15 meter dalam 1 lokasi. Hal tersebut telah sesuai dengan PERMENAKERTRANS No. 4 Tahun 1980 tentang Syarat-Syarat Pemasangan dan Pemeliharaan APAR. Terdapat beberapa APAR yang belum sesuai yaitu cara penggunaannya telah hilang dan juga ada beberapa kotak APAR yang tidak terdapat APAR. Pemeliharaan APAR dilakukan dengan pemeriksaan setiap satu bulan sekali dan pelaporannya setiap 6 bulan sekali yang dilakukan oleh BIRO QHSE. Alat proteksi aktif yang terakhir di PT. Adiluhung Saranasegara Indonesia, Bangkalan adalah Hydrant, Terdapat 2 unit hydrant yang 
tersebar di Perusahaan. Perlengkapan yang terdapat setiap unit hydrant adalah pompa dan motor hydrant yang masing-masing berlokasikan di area Slip way dan Floating Dock. Untuk lokasi area Slip way terdapat 4 pilar hydrant dan terdapat 4 kotak hydrant yang masing-masing berisikan 1 buah Hoze dan 1 buah Nozzle, sedangkan untuk area Floating Dock terdapat 2 buah Nozzle dan 2 buah Hoze.

Penjelasan mengenai sarana proteksi kebakaran pasif yang terdapat di PT. Adiluhung Saranasegara Indonesia, Bangkalan meliputi yang pertama adalah Jalur Evakuasi, Jalur evakuasi ini dilakukan untuk mencegah terjadinya kecelakaan atau luka pada waktu melakukan evakuasi pada saat terjadi kebakaran. Jalur evakuasi menunjukkan arah untuk menuju mustar station yang merupakan tempat berkumpul pada saat keadaan darurat terjadi. Alat proteksi kebakaran pasif selanjutnya adalah Mustar Station, mustar station merupakan tempat berkumpulnya orang yang dievakuasi, lokasinya jauh dari segala macam risiko untuk menjamin agar setiap orang akan aman dari bencana, mustar station juga harus terlindungi dari bangunan yang terkena dampak dari bencana atau terbakar dan harus diletakkan ke tempat yang lebih jauh dari sumber bahaya, pada saat terjadi kebakaran akan ada arahan dari safety master yang akan disampaikan di mustar station pada korban yang telah dievakuasi. Hal ini sudah sesuai dengan Peraturan Menteri Hukum dan Hak Asasi Manusia Republik Indonesia Nomor 28 Tahun 2013 tentang Manajemen Penanggulangan Kebakaran di Lingkungan.

Elemen yang tidak kalah penting adalah inspeksi kebakaran. Banyak terjadi kasus peralatan pemadam tidak dapat berfungsi ketika terjadi kebakaran, hal ini diperlukan untuk memastikan bahwa setiap peralatan kebakaran dapat berfungsi normal. PT. Adiluhung Saranasegara Indonesia, Bangkalan telah sesuai dengan Peraturan Menteri Tenaga Kerja dan Transmigrasi no. Per-04/MEN/1980 tentang Syarat-Syarat Pemasangan dan Pemeliharaan Alat Pemadam Api Ringan (APAR), Inspeksi yang telah dilakukan berupa inspeksi alat-alat pemadam yang berupa APAR dan hydrant. Hal ini perlu dilakukan agar ketika terjadi kebakaran APAR dan hydrant siap untuk digunakan. Oleh karena itu APAR dan hydrant harus diperiksa setiap bulan dan untuk pelaporan nya setiap 6 bulan sekali yang dilaksanakan oleh Biro QHSE. Selain hal tersebut, terdapat juga inspeksi lapangan yang dilakukan oleh Tim Petugas Keamanan dan Disiplin. Inspeksi yang dilakukan oleh Tim Petugas Keamanan dan Disiplin adalah inspeksi lapangan yang berupa pengecekan travo alat las, kelistrikan di seluruh area galangan serta memastikan tidak terdapat kebocoran pada penggunaan gas LPG.

Upaya pengendalian bahaya atau pencegahan terhadap timbulnya kebakaran yang telah dilakukan adalah berupa penyediaan fireman atau petugas pemadam di setiap pekerjaan kapal repair yang berisiko untuk terjadi kebakaran. Menurut Ramli (2010), upaya yang paling penting dilakukan adalah mencegah kebakaran atau menghindari terjadinya kebakaran melalui program pencegahan kebakaran yang dilakukan secara terencana. Fireman mempunyai tugas memastikan kondisi aman dan terhindar dari kondisi yang dapat menyebabkan kebakaran, dan apabila telah terjadi kebakaran seorang fireman mampu memadamkan api sejak terjadi kebakaran kecil. Setiap fireman selalu dibekali dengan APAR apabila menjaga kapal repair karena posisinya yang cukup sulit untuk menggunakan hydrant. Selain hal tersebut, perusahaan juga berupaya pengendalian bahaya atau pencegahan berupa pemasangan rambu-rambu dan larangan merokok di area produksi kecuali di area smoking. Area smoking ini terdapat 4 area yang tersebar di area perusahaan.

Saat kebakaran tidak dapat dihindarkan, maka langkah yang harus dilakukan adalah mengendalikan dengan cepat, tepat dan aman. Pembentukan tim tanggap darurat penting dilakukan untuk menanggulangi bahaya kebakaran pada tahap awal. Tim tanggap darurat sudah terbentuk di dalam perusahaan sejak tahun 2013 dan telah terdapat tugas dan tanggung jawab masing-masing bagian. Di dalam prosedur juga sudah terdapat alur komunikasi yang harus dilakukan ketika terjadi keadaan darurat. Ketika keadaan darurat terjadi di luar jam kerja, maka yang bertanggung jawab atas penanggulangan adalah tim sekuriti, karena tim sekuriti telah dilatih setiap 2 bulan sekali untuk penggunaan APAR dan penggunaan Hydrant.

\section{SIMPULAN}

Pada program pra kebakaran sudah terdapat kebijakan tentang pencegahan kebakaran dan penanggulangan kebakaran, hal tersebut sudah dilakukan dan berjalan di PT. Adiluhung Saranasegara Indonesia, Bangkalan. Sudah terdapat organisasi kebakaran dan telah terdapat tugas dan tanggung jawab masing-masing bagian, terdapat prosedur kebakaran, terdapat identifikasi 
bahaya kebakaran, sudah terlaksana pembinaan dan pelatihan yang dilakukan secara rutin, Sistem proteksi aktif maupun pasif sudah cukup sesuai dan memenuhi kebutuhan perusahaan, sudah terdapat inspeksi kebakaran dan juga telah dilakukan pengendalian bahaya atau pencegahan.

Pada program saat kebakaran sudah terdapat tim tanggap darurat dan telah bekerja sesuai dengan tugasnya masing-masing. Saat keadaan darurat terjadi di luar jam kerja, maka yang bertanggung jawab untuk penanggulangan kebakaran adalah tim security.

\section{DAFTAR PUSTAKA}

Gaspersz, Vincent., 2012. Three-in-one (ISO 9001, ISO 14001, OHSAS 18001). Bogor: Vinchristo Publication

Keputusan Menteri Tenaga Kerja No. Kep-186/ MEN/1999. Tentang Unit Penanggulangan Kebakaran di Tempat Kerja, Jakarta: Kementerian Tenaga Kerja
Peraturan Menteri Hukum dan Hak Asasi Manusia Republik Indonesia No. 28 Tahun 2013. Tentang Manajemen Penanggulangan Kebakaran di Lingkungan, Jakarta: Kementerian Hukum dan Hak Asasi Manusia

Peraturan Menteri Tenaga Kerja No. Per-02/ MEN/1983. Tentang Instalasi Alarm Kebakaran Automatik, Jakarta: Kementerian Tenaga Kerja

Peraturan Menteri Tenaga Kerja No.Per-04/ MEN/1980. Tentang Syarat-Syarat Pemasangan dan Pemeliharaan Alat Pemadam Api Ringan, Jakarta: Kementerian Tenaga Kerja

Peraturan Pemerintah No. 50 Tahun 2012 tentang Penerapan Sistem Manajemen Keselamatan dan Kesehatan Kerja. Jakarta: Pemerintah Republik Indonesia

Ramli, S., 2010. Petunjuk Praktis Manajemen Kebakaran. Jakarta: Dian Rakyat

Undang-Undang No. 1 Tahun 1970 tentang Keselamatan Kerja. Jakarta: Kementerian Perburuhan 